\title{
Educational Horizons of Contemporary Pakistan ${ }^{1}$
}

\author{
Syed Nomanul Haq*
}

When we glance at the intellectual horizons of Pakistan, what appears before our eyes is an intractable mêlée of inconsistent and often conflicting systems, riven by deep fissures and pervasive discontinuities. This situation, not unlike that in practically any contemporary Muslim society, does not mean that there is any inherent or actual intellectual inferiority in these societies. Pakistan itself can boast a vast treasure of talents, skills, and rigor of intellect. But it does engender a marked fragmentation of the country's population.

\section{The Literacy Gap}

Before proceeding, let us set the backdrop with some concrete facts. Pakistan's population is roughly 160 million people, some 70 per cent of whom live in rural areas. The overall literacy figure - and this includes the barely literate as well as those who have learnt to read and write their names - is 57 per cent. Looked at from the darker side, some 43 per cent of Pakistani reading-age citizens are utterly illiterate. In a recent UN Development Program educational survey of 132 countries, Pakistan was ranked abysmally at $126^{\text {th }}$ in GDP spending on education, as compared to Malaysia, which was the $10^{\text {th }}$ in rank. The number of Pakistani graduates from a "modern" university is a mere 6.3 per cent of the total population. As for the non-university educated population (see below), no complete or reliable figures are available — but it has been asserted that this figure, most surprisingly, is much lower, by some counts as low as 1.3 per cent of all enrolled school children. ${ }^{2}$

The picture is bleak indeed. But it becomes even bleaker when we see the incoherence and mutual isolation of "educated" Pakistanis. To begin with, a gross classification divides the literate population into three groups which exist practically in mutual intellectual isolation: liberals, conservatives, and those who just cannot explain themselves, denied the ability to articulate their own condition or their own bearings in history. But here is a word of caution: the labels "liberal" and "conservative" are only to be roughly employed in this case; they do not necessarily denote clearly thought-out, informed, or learned doctrinal positions. The safest thing to assume is that Pakistanis so labelled speak in that particular idiom - whether clearly understood or not - which one finds in the named ideologies or philosophical stances.

But this is a gross classification. As we refine it, we see that the picture becomes messier and messier. The "liberals" are generally—but not exclusively—educated 
in what in standard parlance would be called "modern-secular" institutions, in other words western or western-style educational entities, particularly mainstream colleges and universities. The official press and the vocal partisans of this mainstream group refer to them charitably and approvingly by descriptive appellations such as "forward-looking", "rational", "reasonable", "scientific", and of course "modern". The "conservatives" on the other hand, lying on the periphery in terms of official power and authority, particularly those who have a degree of explicit and often rather unsophisticated ideological rigidity, are generally but not exclusively schooled in madrasahs. Madrasahs have now become a familiar phenomenon of the Islamic world, especially those in Afghanistan, Pakistan, Bangladesh, and Indonesia. They are privately-supported non-government educational institutions with a whole spectrum of curricular structures of their own. They are funded essentially by private donations, charitable gifts, and pious endowments, and are generally run by creed-based associations or alliances. This is all notwithstanding the US administration's mounting anxieties about them after the fateful events of 11 September 2001.

It ought to be noted at the very outset that madrasahs undertake not only purely academic instruction, offering along with it — now necessarily — a range of professional training for the performance of religious functions such as leading congregational ritual prayers, pronouncing legal rulings based on a specific body of articulated religious law (fiqh), carrying out funerals or performing wedding ceremonies. But at the same time they also aim to provide moral education: this dual educational-moral function is declared by them expressly, openly, and emphatically. Often misleadingly called "seminaries", madrasahs operate with a consciously forged Islamic identity with a view to producing better Muslims. Unlike mainstream college and university graduates, as we remarked above, madrasah trained groups are largely the disenfranchised segment of the population, lying on the periphery of the authoritative power of state institutions. Despite some small political representation of these non-university trained people in the parliament through the ballot, they have no direct role in the administrative, judicial or legislative operations of the state - they are effectively disenfranchised citizens.

This leads us to a further taxonomic complication: the three "literate" communities we have identified and loosely labelled-namely, liberals, conservatives, and the inarticulate voiceless - reflect almost perfectly Pakistan's socio-economic classes. Enrolments in standard official institutions of the educational mainstream practically always comes from the elite down to the lower middle classes - that is, from those classes constituted by feudal lords through urban entrepreneurs and high state officials, all the way underneath to the likes of lower-level army recruits, small marketplace vendors, and office clerks. It is hard 
to imagine well-to-do businessmen or government ministers, diplomats, lawyers, or journalists even thinking of sending their children to a madrasah for their main education. Only the downtrodden, the orphans, the daily-wage labourers- the economically poorer and socially lower classes-look to madrasahs as a source of education for their young. The third fragment- the voiceless-are produced from either of these two systems of schooling: mainstream institutions and peripheral madrasahs. This will become clear as we identify dangerous internal fragmentation within these two systems.

\section{Shift in Madrasah Focus, Ideology Formation and Deepening Contrasts}

These divisions do not of course correspond to any differences in people's abilities, talents, intelligence, or creativity. Nor do these classifications necessarily or essentially mark any hierarchy or gradations of what one would call academic or intellectual excellence in its purest sense. Thus, counter-intuitive as it may seem, one of the most formidable scholars of Pakistan, perhaps the most formidable to gain an international reputation, was Fazlur Rahman - himself a madrasah product and son of a madrasah-educated mosque imām. This founder of the famous Islamic Research Institute in Islamabad rose to the stature of Harold H. Swift Distinguished Service Professorship of Islamic Thought at Chicago University and received the prestigious Levi Della Vida award for excellence in scholarship presented by UCLA. In the entire history of Pakistan, no scholar of the humanities trained throughout in an official college or university has so far attained such high academic station. There are other similar cases as well.

In the same vein, we need to understand that vocational work has only recently become the mainstay of madrasahs, for example, training of imāms for ritual services, or running a supply line to provide professionals such as Qur'ānHadith-Fiqh teachers in the mainstream schools where "Islämiyyât " (Islamics) is a graduation requirement; or preparing muftīs to pronounce Islamic legal rulings. Traditionally, while the production of this kind of religious service personnel had certainly remained an integral part of the madrasah curriculum, it was not its chief calling. Rather, the main focus had been intellectual, to rear and groom a body of 'Ulamā', literally, 'learned scholars'. Indeed, certain madrasahbased schools of thought preoccupied themselves exclusively with rational and philosophic disciplines and did not earn their livelihood as religious functionaries at all, taking no actual interest in tactical politics or even in the affairs of state, and involving themselves in rituals no more than any other ordinary Muslim. They were primarily thinkers and intellectuals. An eminent case of this rational theoretical trend is the redoubtable Khayrabadi logical-philosophical school, 
which has all but disappeared now and is all but forgotten as well. The writings of Muhammad Qasim Zaman of Princeton and Asad Ahmed of Berkeley are most instructive here. ${ }^{3}$

So it ought to be kept in view that a major shift in madrasah focus has taken place in most recent times, particularly after the USSR's invasion of Afghanistan at the turn of the decade of the 1980s. Today, with a few exceptions, madrasahs are not typically generating an alternative intellectual class, a class arising from a non-Western curricular world. They are giving to the society only what may be called vocationally-trained personnel for carrying out rituals and religious services, prepared without any rigorous academic quality control. Strictly speaking, and notwithstanding certain notable exceptions, these contemporary madrasah products are not really 'Ulamā', although they are generically referred to by this title. Small wonder, then, that there exists today a sharp contrast between a university graduate and a madrasah graduate - the latter turns out to be inarticulate in comparison, rather ill-trained, and does not seem to speak in the current idiom of our globalised era. This only deepens the intellectual and social divide in Pakistani society, yielding the fragmentation referred to above.

Given the correlation between socioeconomic status and enrolment in madrasahs, the second thing to take note of is this: the ideologies formed in these institutions today, disenfranchised as they are, arise in the context of poverty, powerlessness and often the lack of nurturing family support. In this regard, it is important to keep in view that, unlike mainstream public educational institutions and the majority of private ones, a high percentage of madrasahs are residential schools charging nominal fees, if at all, providing full board to their student body - and therefore they exercise a more profound and an all-embracing impact on the lives of students. Indeed, given their dual educational-moral role, madrasahs teach an entire lifestyle ranging from personal physical appearance and rules of dress, food, topics of conversation and manners, to performance of rituals, extracurricular duties, homework and examinations. Again, this contrasts sharply and most significantly with the mainstream educational institutions.

Typically, madrasahs are also involved in works of social welfare. They collect alms and charity for their own use and for distribution to the needy, sometimes help widows financially, arrange funerals for the dead among the indigent, and here and there even run free medical clinics for the treatment of the sick in the neighbourhood. Above all, these madrasahs, especially those existing in rural settings, frequently provide shelter to orphan boys and less frequently to preteenage orphan girls. Generally, as soon as they come of age, girls are married off to local families, while boys continue their education and training until the time of graduation when they are certified by their teachers formally as qualified religious service professionals, 'licensed' to become teachers themselves. All this 
further deepens the contrast between this peripheral educational-moral world of madrasahs and the world of Pakistan's mainstream educational system.

\section{Apartheid within Apartheid: Mainstream School Educational Systems}

Thus, madrasahs and the mainstream institutions constitute a yawning dichotomy of two incommensurable universes - manifesting a quasi apartheid in world-view and self-awareness. Furthermore, there exists an intractable apartheid within this apartheid. To begin with, when we come to the mainstream universe, we find two further fissures: on the one hand, public institutions run by the government, funded by the Education Ministry in the case of pre-college schools, and by the Higher Education Commission in the case of post-secondary school educational centres. On the other hand, a massive parallel body of private institutions, either run by entrepreneurs for making profit, or by philanthropists for serving the cause of education. By far the most prominent among the latter is certainly Syed Babar Ali who is the chief founder of Lahore University of Management Sciences (LUMS), but one must not fail to mention Hakim Muhammad Saeed, who founded the less successful Hamdard educational enterprise in Karachi.

As for public primary and secondary schools, their condition could be described as pitiful. There exist on paper many primary government schools, particularly in rural areas and small towns, which lack a proper building fit for human use; if they do have buildings of their own, they stand precariously in dilapidated disrepair and abject neglect. Sometimes there is no electricity, no water supply, no roof and not even a concrete floor. Multiple classes are sometimes held in the same room simultaneously, and basic supplies including chalk sticks for blackboards are a hard find. Teachers and young children in large numbers must travel for miles to get to these 'schools', no transport arrangements whatsoever being available for them. While the quality of teaching is abysmal in these schools, there also exist virtual schools: schools which do not even have teachers. The story of government-run secondary schools is slightly less heartrending, but only slightly.

The fees charged by public schools in Pakistan are nominal indeed, as they cater to the lowest rungs of the lower middle class. But when we turn to the private primary and secondary schools, more complications arise. Pakistan has a plethora of mainstream private schools, found virtually in every urban alley or in every town neighbourhood, sometimes housed in purpose-built accommodations but more often in converted residential buildings in densely populated areas. Very frequently many of these are found to be unregistered and thereby 'illegal', and occasionally but not always they are closed down upon discovery. The quality, mission, and fee structure of these private sector institutions vary enormously; 
they display what statisticians would describe as a very high standard deviation. In other words, there exist those private schools whose fee is just a few times larger than those of their public counterparts, while there exist elite academies affordable only by the very wealthy whose fees are as high as a massive 140 times that of a typical government school.

Among these private educational enterprises, one finds those that are barely any better than the public ones. Yet at the same time there are those high-class private schools whose academic quality, discipline, and social training are uncompromisingly rigorous and superior, comparable to any top school in the Western world. The private sector mission varies widely as well: some are run by Christian missionaries; some continue to operate as leftovers from British colonial times serving as exclusive schools for the upper classes which were originally meant to prepare higher level civil servants, now in Anglicized Pakistani hands; others are unashamedly for-profit commercial enterprises, while yet others came into existence through a gesture of philanthropy. Their products show equally wide variations in the value of their training, their subsequent career, and their ideological leaning. The loudly advertised fundamental claim of the 'distinction' of private schools is that they are English medium institutions, where instruction is given not in the national or any regional Pakistani language but only in English. This stands in contrast to government Urdu medium schools for the lowly commoners'. However a new trend in the latter is visible these days: some provincial governments have vowed to translate their public schools gradually into English medium institutions. This abrupt emulation of the private sector is creating academic, social, and ideological dislocations of drastic proportions.

\section{Pakistan's Pre-University Curricular Market Place}

The apartheid within apartheid goes even deeper. While madrasahs and mainstream schools differ entirely from each other in their curricula and testing systems, within mainstream schools themselves there are to be found not one but as many as six different, incompatible curricular systems, examination mechanisms, and certification policies. Most government schools and quite a large number of private schools, especially the lesser ones, follow the statedesigned curriculum leading to a Secondary School Certificate and then to a Higher Secondary Certificate. The examinations are administered by the Board of Intermediate and Secondary Education. Nevertheless, some schools also offer non-academic vocational training which is separately designed, administered, and certified.

When we turn to the more expensive elite private schools, we do not find a single or unified integrated system either. Most of these institutions teach the well- 
known British Ordinary (O)-Level and Advanced (A)-Level curriculum, all in English except for the language-specific literature courses. This imported system, based both conceptually and administratively outside of Pakistan's cultural boundaries, is governed from afar by the prestigious Cambridge University which is its examining authority. The examinations are administered locally not by the schools themselves but by the British Council in Pakistan, an official UK body with a Royal Charter. But there is even more in this Pakistani education market place. There exist in the country some private schools which take yet another route: that of the International Baccalaureate (IB), a Geneva-based system that was developed privately in the late 1960s and now operates from Switzerland by an NGO recognised by the Council of Europe. Again, while the teaching of the IB curriculum is carried on inside Pakistan, examinations and certification are controlled and conducted directly by the Swiss IB Organization, away from Pakistan both in terms of physical distance and in terms of its civilisational distance from indigenous culture.

There is a fifth system operating in the mainstream. Certain elite schools and those United States Embassy-affiliated academies constitute the genre of 'American Schools' in Pakistan. While these establishments follow curricula conceived and taught in United States, institutionally they operate fully within Pakistan, given that there is in general no centralised school examinationcertification authority in the US, and such schools are run as practically autonomous bodies. Finally, there is yet another product in the mainstream school education market: the Aga Khan Board. This private Board run by the Ismā' $\overline{1} 1 \overline{1}$ religious community headed by the Aga Khan is conceived with a non-sectarian secular vision and offers its own matriculation system.

\section{The Fragments}

When we include madrasahs in our rough and broad survey, we observe seven different basic educational systems running in Pakistan. If we bear in mind also that madrasahs themselves severally follow a whole variety of curricula, with their many rival creed-based leanings, the number of these systems will swell manyfold in our reckoning. As we have noted above, in terms of academic quality there exists an intractable complex web with an enormously wide spectrum of gradations within and across the systems.

Out of this chaotic field, four major incommensurable communities vie in the embodiment of Pakistan's literate minority: the elite English-medium private school graduates; those who emerge from the lower-standard Urdu medium government schools; the Madrasah-educated community; and finally those inarticulate barely educated crowds who attend the lowest quality academies, 
whether public or private or of the madrasah genre. These four groups inhabit what are virtually four different universes - they speak in different idioms, they move in different social groups, the food they eat and the clothes they wear are dissimilar, and their careers and life aspirations manifest deep class divides. The formal language of one of them, the elite, is English, whereas the language of the rest is the national language Urdu. This is a portrait of a fragmented society.

\section{Notes}

* Syed Nomanul Haq, Senior faculty member and Chair of the Residential Colleges at the Lahore University of Management Sciences (LUMS), he is General Editor of OUP's Studies in Islamic Philosophy series, and Chief Editor of the Urdu Studies journal Bunyaad. Previously a faculty member at Brown University and the University of Pennsylvania, he has broad expertise in the field of medieval Islamic intellectual history including the history of Persian, and Urdu literature. He won a postdoctoral fellowship at Harvard University, and shared the prestigious Waldo Leland Prize of the American Historical Association for his chapters in the New Cambridge History of Islam. Syed Nomanul Haq's books are published by Harvard University Press, and Oxford University.

1. This is my summary of a lecture which I delivered this past summer at IAIS. As it stands, it has two limitations that need to be pointed out at the very outset: (1) The study refers to, but does not examine in any detail, the official higher educational systems in Pakistan. It is limited to a consideration of basic education offered in mainstream pre-university primary and secondary schools, and in madrasahs that lie on the peripheries. (2) The account is impressionistic and essentially qualitative; it moves without citing much supporting statistical data.

2. I have drawn upon the following sources for these statistics:"Education Statistics: Education Spending (\% of GDP) (Most Recent) By Country," Nation Master, available online at http://www. nationmaster.com/graph/edu edu spe-education-spending-of-gdp; "Literacy Rate \& Education Statistics," Pakistan Literacy, available online at http://pakistanliteracy.wikispot.org/Statistics; "Population of Pakistan - Statistics," Population Association of Pakistan, available online at http://www.pap.org.pk/statistics/population.htm\#tabfig-1.1; "Madrassas vs Private Schools in Pakistan," Irtiqa: A Science \& Religion Blog, 8 July 2009, available online at http://www.irtiqablog.com/2009/07/madrassas-v-private-schools-in-pakistan.html; A good body of statistical data appears in Tariq Rahman, Denizens of Alien Worlds: A Study of Education, Inequality and Polarization in Pakistan (Karachi: Oxford University Press, 2004).

3. See Asad Ahmed, "The Place of Logic in the Curriculum of the Khayrabadi School: From Imam-i Haqq to Muntakhabul Haqq" in: Michael Cook, Najam Haider, Intisar Rabb and Asma Sayeed (eds.), Law and Tradition in Classical Islamic Thought: Essays in Honor of Professor Hossein Modarressi (New York: Palgrave Macmillan, forthcoming); Muhammad Qasim Zaman, The Ulama in Contemporary Islam: Custodians of Change (Princeton NJ: Princeton University Press, 2002). 